\title{
Pembekalan mental dan keterampilan pembuatan sabun padat pada anak binaan Panti Asuhan dan Tahfidz Amanah Kaharu Sudiang
}

\author{
Taufiq Dalming ${ }^{*}$, Dedy Ma`ruf ${ }^{2}$ \\ 'Sekolah Tinggi Ilmu Kesehatan Pelamonia Makassar, Makassar, Indonesia. \\ 2Institut Ilmu Kesehatan Pelamonia Kesdam XIV/ Hasanuddin, Makassar, Indonesia
}

\section{DOI: https://doi.org/10.29303/indra.v2i1.46}

\section{Article Info}

Received : 31-07-2020

Revised : 27-04-2021

Accepted: 28-04-2021

\begin{abstract}
Soul provision and skills of making Solid soap for the children assisted by the orphanage and tahfidz amanah Kaharu Sudiang are alternative activities in the context of strengthening the Islamic personality and provision of independence. Activities carried out in the form of demonstrations of making solid soap, mentoring, and watching movies together. The activity received good responses from the assisted children and participated in the activity enthusiastically. This activity became the starting point for similar activities with other themes.
\end{abstract}

Keywords: Soul provision, making solid soap, assisted children at the orphanage and Tahfidz Amanah Kaharu

Citation: Dalming, T., \& Ma'ruf, D. (2021). Pembekalan Mental dan Keterampilan Pembuatan Sabun Padat pada Anak Binaan Panti Asuhan dan Tahfidz Amanah Kaharu Sudiang. INDRA Jurnal Pengabdian kepada Masyarakat, 2(1), 1214. doi: https://doi.org/10.29303/indra.v2i1.46

\section{Pendahuluan}

Panti Asuhan dan Tahfidz Amanah Kaharu Sudiang merupakan salah satu tempat yang menjadi tumpuan bagi anak-anak yatim berasal dari berbagai daerah di Indonesia. Sebagian dari anak yatim merupakan anak yang mulai dibina sejak bayi dan balita yang belum sepenuhnya merasakan kasih sayang dari orang tua mereka. Keterbatasan fasilitas, finansial, kurangnya pembinaan menjadi beberapa kendala yang dihadapi banyak panti asuhan, termasuk Panti Asuhan dan Tahfidz Amanah Kaharu Sudiang. Sehingga dengan kontribusi memberikan pendampingan kepada anak-anak binaan panti berupa pembinaan mental dan keterampilan pembuatan sabun padat menjadi hal yang perlu dilaksanakan yang akan menjadi bekal mental dan keterampilan pada anak-anak yatim.

Pembinaan mental merupakan usaha untuk memperbaiki atau memperbaharui suatu tindakan atau tingkah laku seseorang melalui bimbingan mental/ jiwanya sehingga memiliki kepribadian yang sehat, akhlak yang terpuji dan bertanggung jawab dalam menjalani kehidupannya (Firdaus, 2014). Kepribadian yang ideal dan unik dapat diperoleh oleh seseorang tatkala terbentuk dari dirinya pola pikir dan pola sikap yang didasari oleh suatu landasan aqidah Islam, sebagaimana kepribadian Islam terdiri dari pola pikir dan pola sikap Islam (Mutaharoh, 2014).

Peran pembinaan mental dalam rangka merangsang pada seseorang hingga terbentuk dari dirinya pola pikir dan pola sikap yang khas. Di samping kepribadian yang baik seseorang juga perlu mendapatkan pembekalan kemandirian sebagai bekal dalam menjalani kehidupannya. Upaya yang dapat dilakukan dengan mengasah keterampilan dasar sebagai manusia, melatih aspek psikomotorik pada seseorang. Pada program ini memperkenalkan dan memberikan pengalaman dalam pembuatan sabun 
padat kepada anak binaan Panti Asuhan dan Tahfidz Amanah Kaharu Sudiang.

Pembuatan sabun dapat dilakukan dengan dua cara yaitu proses saponifikasi dan proses netralisasi minyak. Proses saponifikasi minyak akan memperoleh produk sampingan yaitu gliserol, sedangkan proses netralisasi tidak akan memperoleh gliserol. Prinsip saponifikasi terjadi karena reaksi antara trigliserida dengan alkali, sedangkan prinsip netralisasi terjadi karena reaksi antara minyak dengan alkali (Widyasanti, dkk, 2016).

Pembekalan mental dan keterampilan pembuatan sabun diharapkan menjadi perpaduan yang dapat menjadi maklumat awal atau modal yang penting bagi anak binaan guna pelatihan dini untuk kemandirian.

\section{Metode}

Kegiatan pengabdian kepada masyarakat dilaksanakan di lingkungan Panti Asuhan dan Tahfidz Amanah Kaharu Sudiang. Kegiatan dilaksanakan dalam bentuk penyuluhan, demonstrasi pembuatan sabun padat, pemutaran film edukatif. Dengan metode tersebut diharapkan anak binaan mengetahui dan mampu membuat sabun padat.

\section{Hasil dan Pembahasan}

Program dimulai dengan melakukan survei tempat dan pengajuan program kepada pihak pengelola panti asuhan. Hasil pengajuan ditetapkan waktu rutin pembinaan disela-sela kegiatan anak binaan yaitu setiap akhir pekan dan salah satu agenda pembinaan adalah praktik pembuatan sabun padat.

Kegiatan pembekalan keterampilan pembuatan sabun padat dilaksanakan di Panti Asuhan dan Tahfidz Amanah Kaharu Sudiang dan dihadiri oleh 20 orang putra putri anak binaan panti serta didampingi oleh 5 orang mahasiswa Program Studi D3 Farmasi STIKes Pelamonia. Pembekalan dilaksanakan dalam bentuk demonstrasi pembuatan sabun dan penjelasan mulai menyiapkan bahan, bahan dapat diperoleh dari mana, peralatan yang digunakan, hingga prosedur pengerjaan pembuatan sabun.

Metode pembuatan sabun padat yang dilaksanakan dengan mencampurkan antara fraksi lemak dalam hal ini minyak sawit yang bisa diperoleh di warung-warung dengan alkali $\mathrm{NaOH} 30 \%$, metode ini merupakan cara untuk membuat stok sabun (Rita dkk, 2018). $\mathrm{NaOH}$ tidak harus diperoleh dari toko bahan-bahan kimia, tapi biasa juga tersedia di toko bahan bangunan karena selain untuk pembuatan sabun juga digunakan untuk mengatasi penyumbatan pipa atau saluran pembuangan air.

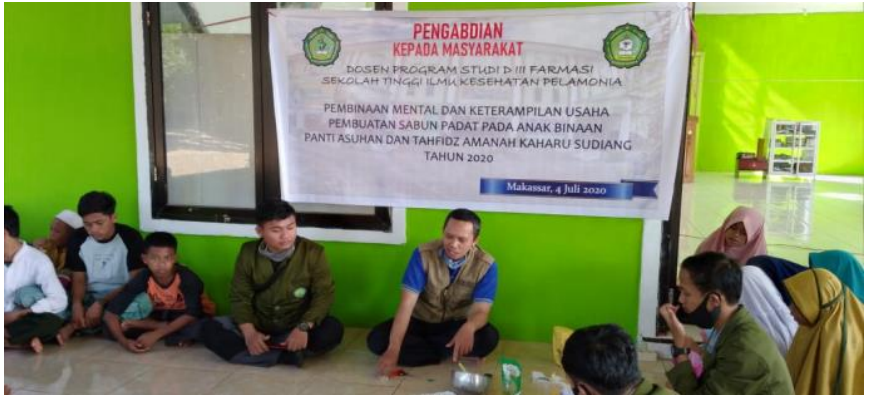

Gambar 1. Demonstrasi pembuatan sabun

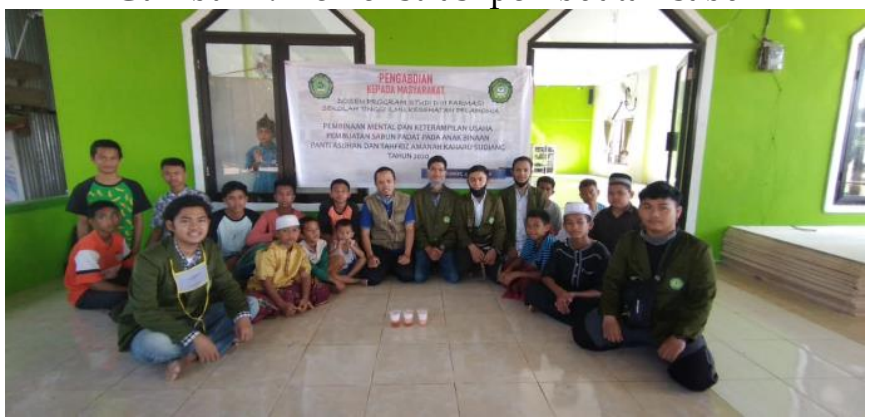

Gambar 2. Foto bersama setelah demonstrasi pembuatan sabun

Pembekalan mental dilaksanakan dalam beberapa bentuk kegiatan penyampaian materi, pendampingan dalam kegiatan bermain, dan nonton film sejarah bersama. Hasil kegiatan dipahami dari antusias anak-anak dan perubahan sikap dari sebelum dan setelah pelaksanaan kegiatan. Selain itu kegiatan ini menjadi pintu awal untuk keberlanjutan kegiatankegiatan serupa dengan tema keterampilan yang lebih variatif.

Pembekalan mental merupakan bentuk input peningkatan pengetahuan, dengan pengetahuan diharapkan dapat menimbulkan perubahan sikap ke arah yang lebih baik (Citrawathi, 2014).

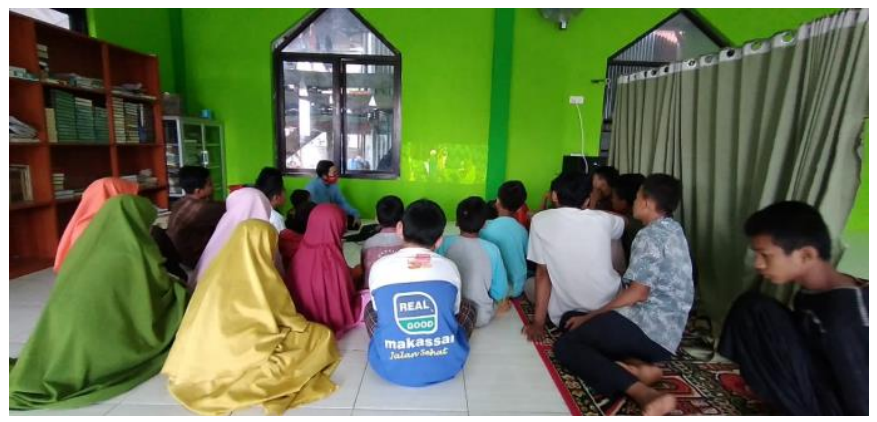

Gambar 3. Suasana nonton film bersama

\section{Simpulan}

Kegiatan pengabdian kepada masyarakat (PKM) berhasil dilaksanakan melalui penyuluhan dan pendampingan. Program ini menjadi pengalaman baru anak binaan serta menjadi kegiatan alternatif di selasela rutinitas anak binaan. PKM juga menjadi pendorong jiwa kemandirian dengan tetap 
memperhatikan landasan Islam sebagai pembentuk pribadi muslim yang baik.

\section{Ucapan Terima Kasih}

Terima kasih kami sampaikan kepada Sekolah Tinggi Ilmu Kesehatan Pelamonia Makassar yang telah terus mendorong kami dalam melaksakan pengabdian kepada masyarakat. Begitupun juga kepada pihak pengelola dan Pembina Panti Asuhan dan Tahfidz Amanah Kaharu Sudiang yang telah memberikan kesempatan kepada kami dalam pelaksanaan kegiatan ini dan Juga tak akan kami lupa para anak binaan panti semoga kelak menjadi insan-insan yang sukses.

\section{Daftar Pustaka}

Citrawathi, D. M., 2014, Pengembangan Model Pendidikan Kesehatan Integratif dan Kolaboratif di Sekolah, Seminar Nasional FMIPA UNDIKSHA IV Tahun 2014.

Firdaus, Ida. (2014). Upaya Pembinaan Rohani dan Mental. Al-AdYaN/Vol.IX, N0.1/Januari-Juni/2014

Mutaharoh, Siti. (2014). Pandangan Taqiyuddin anNabhaniTentang Kepribadian Islam yang dapat Diaplikasikan dalam Bimbingan Konseling Islam. Skripsi; Jurusan Bimbingan Konseling Islam, Fakultas Dakwah dan Komunikasi, UIN Sunan Kalijaga, Yogyakarta.

Rita, W.S., Vinapriliani, N. P. E., Gunawan, I. W. G., 2018, Formulasi Sediaan Sabun Padat Minyak Atsiri Serai Dapur (Cymbopogon citratus DC.) sebagai antibakteri Terhadap Escherchia coli Dan Staphlylococus aureus, Cakra Kimia (Indonesian EJournal of Applied Chesmistry) Volume 6 Nomor 2, Desember 2018.

Widyasanti, A., Putri, S.H. dan Dwiratna S.N.P., (2016), Upaya Pemberdayaan Masyarakat Melalui Pelatihan Pembuatan Produk Sabun Berbasis Komoditas Lokal Di Kecamatan Sukamantri Ciamis, Dharmakarya: Jurnal Aplikasi Ipteks untuk Masyarakat Vol. 5 No. 1. 